\title{
Disomic chromosome addition from Thinopyrum intermedium to bread wheat appears to confer stripe rust resistance
}

\author{
Linman Nie $\cdot$ Yuening Yang $\cdot$ Jun Zhang $\cdot$ Tihua Fu
}

Received: 26 November 2018/Accepted: 12 February 2019/Published online: 21 February 2019

(C) The Author(s) 2019

\begin{abstract}
A wheat line 14-569 developed from a hybrid of common wheat cv. Chuannong 10 with the wheat-Thinopyrum intermedium partial amphiploid TAI7045 exhibits stable double spikelets per node character in the lower middle portion of a spike, is highly resistant to stripe rust, and produces kernels with a higher 1000-kernel weight than those of its wheat parent. Chromosome counting and an analysis of meiosis demonstrated that line 14-569 is a disomic addition line with $2 \mathrm{n}=44$, 22II. Sequential genomic in situ hybridization and non-denaturing fluorescence in situ hybridization analyses indicated that one pair of St-genomic chromosomes from Th. intermedium was added to the wheat complement and that the wheat complement included one pair of 1RS/1BL wheat-rye translocation chromosomes. PCR-based landmark unique gene molecular marker analysis revealed that the added pair of chromosomes comprised 3St chromosomes, which suggested that the added 3St chromosomes from Th. intermedium might carry the genes to control the high yield-related characters and stripe rust resistance. This addition line will potentially be useful resource for improvements in wheat yields and stripe rust resistance.
\end{abstract}

L. Nie $\cdot$ Y. Yang $\cdot$ J. Zhang $\cdot$ T. Fu ( $ه)$

College of Agronomy, Sichuan Agricultural University, Chengdu 611130, Sichuan, China

e-mail: futihua@sina.com
Keywords Wheat $\cdot$ Thinopyrum intermedium Alien addition line $\cdot$ In situ hybridization · PLUG marker

\section{Introduction}

Wheat stripe rust, caused by Puccinia striiformis Westend. f. sp. tritici Eriks., is one of the most damaging diseases of wheat and seriously reduces the yield and quality of wheat worldwide (Roelfs et al. 1992). Yield losses caused by stripe rust can reach $75-100 \%$ in the most severe epidemic years under weather conditions that favor the pathogen (Chen 2005b). The most economical, effective and environment-friendly approach for controlling this disease comprises the cultivation of resistant cultivars (Line and Chen 1995). More than 70 genes that confer resistance to stripe rust have been identified in wheat (McIntosh et al. 2017). However, rapid changes in the virulence of pathogen populations easily overcome the resistance genes in released wheat cultivars. Hence, new resistance resources for stripe rust are continuously required to breed new resistant wheat cultivars. The relatives of wheat possess plenty of desirable genes, including disease-resistance and yield-related genes, for wheat breeding, and these genes can be introduced into wheat by wide crosses and genetic manipulation (Jiang et al. 1993).

Thinopyrum intermedium (Host) Barkworth \& D.R. Dewey [syn. Agropyron intermedium (Host) Beauvoir 
and Elytrigia intermedia (Host) Nevski] is a perennial hexaploid species $(2 \mathrm{n}=6 \mathrm{x}=42)$ with the $\mathrm{JJ}^{\mathrm{s}} \mathrm{St}$ genome (Chen et al. 1998). This species has been proved to be a potential source of genes for improving disease resistance, yield potential (Chen 2005a; Tang et al. 2000) and tolerance of salt stress (Li et al. 2008). To date, numerous intergeneric hybrids and cytogenetic stocks, including wheat-Thinopyrum partial amphiploids (Fedak and Han 2005; Sun 1981; Yang et al. 2006) and wheat addition, substitution, and translocation lines (He et al. 1989; Li et al. 2015; Liu et al. 2011), have been developed. However, because this species is distributed in different regions worldwide, the extensive genetic diversity present in different accessions of Th. intermedium enables the continuous introduction individual chromosomes from Th. intermedium that confer new traits into different genetic background of common wheat.

During the process of transferring desirable genes from Th. intermedium into common wheat, a disomic addition line with stripe rust resistance and a stable double spikelet appearance was obtained. In the present study, we used genomic in situ hybridization (GISH), non-denaturing fluorescence in situ hybridization (ND-FISH) and molecular marker techniques to identify alien chromosomes in wheat lines derived from crosses with Th. intermedium.

\section{Materials and methods}

Plant materials

The Th. intermedium accession PI595172 and the Pseudoroegneria spicata (St genome, $2 \mathrm{n}=2 \mathrm{x}=14$ ) accession PI232131 were obtained from the Triticeae Research Institute, Sichuan Agricultural University. Line 14-569 was a disomic addition line isolated in the progeny of which the partial amphiploid of wheat and Th. intermedium, TAI7045 $(2 \mathrm{n}=56)$ was repeatedly backcrossed to wheat cultivar Chuannong 10 (CN10). CN10 is a wheat-rye 1RS/1BL translocation cultivar with high susceptibility to stripe rust (Yang et al. 2014). The rye, Secale cereal L. 'Jingzhou Heimai' (genome RR) and the wheat cv. Chinese Spring (CS) are maintained at the Ya'an Experimental Station of Sichuan Agricultural University, China.
Evaluation of yield-related traits and reactions to stripe rust inoculation

The evaluation of yield-related traits and reactions to rust inoculation were carried out during the growing seasons of 2014 and 2015 in a field at the Ya'an Agricultural Experimental Station, Sichuan Agricultural University. Plants were arranged separately in a randomized complete block design using two replicates. Twelve plants were randomly selected from line 14-569 and its wheat parent CN10, to assess yieldrelated traits, such as tillering, spike length, the numbers of kernels, spikelets, and double spikelets per spike, the 1000-kernel weight, and plant height. Student's $t$ test was used to test for significant differences between line 14-569 and its wheat parent CN10. A mixture of races of $P$. striiformis, which mainly consisted of CYR31, CYR32, CYR33 and CYR34, which are prevalent in China, was provided by the Plant Protection Institute, Sichuan Academy of Agricultural Science and was artificially inoculated in early spring. The infection type (IT) was recorded when uredinia were fully developed on the leaves during the flowering stage.

Cytogenetic analysis

Seeds were germinated in Petri dishes at $23{ }^{\circ} \mathrm{C}$ in the dark until the roots reached a length of $1-2 \mathrm{~cm}$. The roots tips were excised from the germinated seeds and treated with nitrous oxide gas for $2 \mathrm{~h}$. Then, the treated root tips were fixed in ice-cold $90 \%$ acetic acid and stored in $70 \%$ ethanol at $4{ }^{\circ} \mathrm{C}$ until used (Kato et al. 2004). Chromosome spreads of materials were prepared using the methods described by Han et al. (2006). Pollen mother cells (PMCs) were collected from young spikes and fixed in absolute ethanol/ chloroform/glacial acetic acid (6:3:1, v/v/v). Meiotic chromosomes were flattened on a slide in a drop of $1 \%$ acetocarmine.

The genomic DNA from Th. intermedium and Ps. spicata was labeled with digoxigenin-11-dUTP (fluorescein isothiocyanate detected by yellow-green fluorescence) (Roche), and the rye DNA was labeled with Texas Red-5-dUTP (Invitrogen). Sheared genomic DNA from CS wheat was used as a blocker. OligopSc119.2-1 and Oligo-pTa535-1 were labeled at the 5' end with 6-carboxyfluorescein (green color) and 6-carboxytetramethylrhodamine (red color), 
respectively. The two oligonucleotide probes were synthesized by Shanghai Invitrogen Biotechnology Co., Ltd. (Shanghai, China). GISH and ND-FISH were performed as described by Han et al. (2006) and Fu et al. (2015), respectively.

\section{Molecular marker analysis}

Total genomic DNA was extracted from the fresh leaves. Polymerase chain reaction (PCR)-based landmark unique gene (PLUG) primers were employed (Ishikawa et al. 2009). The PCR amplification conditions were as follows: after denaturation for $5 \mathrm{~min}$ at $94{ }^{\circ} \mathrm{C}$, amplification was performed for 35 cycles, each of which consisted of $45 \mathrm{~s}$ at $94{ }^{\circ} \mathrm{C}, 45 \mathrm{~s}$ at $57{ }^{\circ} \mathrm{C}$, and $2 \mathrm{~min}$ at $72{ }^{\circ} \mathrm{C}$, followed by incubation for $7 \mathrm{~min}$ at $72{ }^{\circ} \mathrm{C}$. Aliquots of $3 \mu \mathrm{L}$ of each PCR amplification product after enzyme digestion was separated in $8 \%$ non-denaturing polyacrylamide gel and visualized by staining with silver.

\section{Results}

Morphology and stripe rust resistance

Line 14-569 displayed the stable double spikelets per node emerging in the lower middle portion of a spike (Fig. 1a, b). The average numbers of double spikelets and seeds produced by double spikelets per spike were 7 and 8, respectively (Table 1). Line 14-569 produced plump red seeds that were similar to those of $\mathrm{CN} 10$, but these seeds had a higher 1000-kernel weight (about $52 \mathrm{~g}$ ) (Table 1 and Fig. 1c). This line also produced more spikelets and seeds per spike and had a greater spike length. Student's $t$ test showed that line 14-569 was very significantly different from $(P<0.01)$ its wheat parent $\mathrm{CN} 10$ in terms of most tested characters, except plant height which was only significantly different a level of $P<0.05$ (Table 1). These results for agronomic traits indicated that line 14-569 probably carried genes that were beneficial for agricultural production.

When artificially inoculated with a mixture of races of $P$. striiformis, including CYR31, CYR32, CYR 33, and CYR34, during the growing season, line 14-569 was highly resistant (IT 0) to these isolates, whereas the wheat parent CN10 was highly susceptible (IT 4)

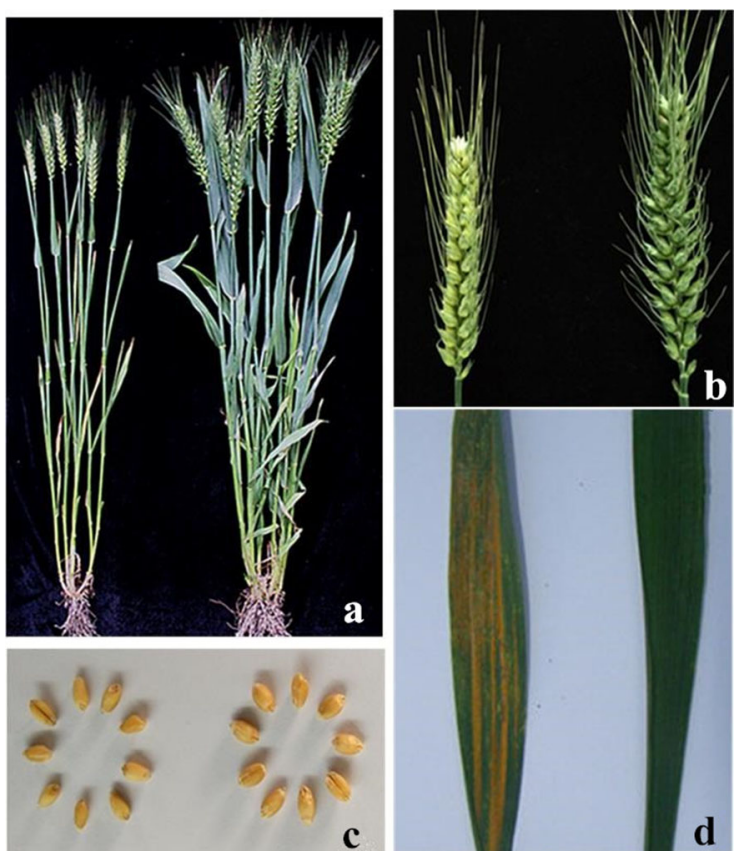

Fig. 1 Morphology of whole plant (a), spike (b), seeds (c) and stripe rust resistance (d) of common wheat $\mathrm{CN10}$ (left) and line 14-569 (right)

(Fig. 1d), which implied that line 14-569 might carry a gene or genes that conferred resistance to stripe rust.

Cytogenetic analysis

Root tip chromosome counts and observations of meiosis of PMCs on twenty plants from line 14-569 indicated that all these plants had a constant number of 44 chromosomes and formed 22 bivalents at metaphase I of meiosis, which demonstrated that line 14-569 might be a stable alien disomic addition line.

GISH analysis that employed DNA from $T h$. intermedium as probe on mitotic metaphase chromosomes of line 14-569 demonstrated that two pairs of chromosomes that gave rise to strong yellowish-green hybridization signals were present, of which one pair exhibited signals uniformly along their entire length, whereas the other pair only exhibited strong GISH signals in one of the telomeric regions (Fig. 2a). Sequential ND-FISH analyses using the OligopSc119.2-1 and Oligo-pTa535-1 probes revealed that the pair of chromosomes labeled in the telomeric regions with the DNA from Th. intermedium might be 1RS/1BL translocations (Fig. 2b). This result was corroborated by further sequentially using the DNA 
Table 1 Morphological characters of line 14-569 and its wheat parent $\mathrm{CN} 10$

*Significant differences between the means are indicated at levels of $P<0.01$ (capital letters) and $P<0.05$ (lower-case letters), according to Student's $t$ test

\begin{tabular}{lcc}
\hline Character & CN10 & $14-569$ \\
\hline Plant height $(\mathrm{cm})$ & $84.2 \pm 4.08 \mathrm{Aa}^{*}$ & $90.1 \pm 3.50 \mathrm{Ab}$ \\
Spikes/plant & $4.4 \pm 0.78 \mathrm{~A}$ & $7.2 \pm 1.59 \mathrm{~B}$ \\
Spike length (cm) & $10.4 \pm 0.96 \mathrm{~A}$ & $12.6 \pm 0.92 \mathrm{~B}$ \\
Spikelet/spike & $18.9 \pm 1.89 \mathrm{~A}$ & $23.7 \pm 1.83 \mathrm{~B}$ \\
Kernels/spike & $45.0 \pm 3.0 \mathrm{~A}$ & $52.5 \pm 3.39 \mathrm{~B}$ \\
Double spikelets/spike & 0 & 7 (range 5-8) \\
Kernels produced by double spikelets/spike & 0 & 8 (range 5-11) \\
1000-Grain weight & $41.1 \pm 2.32 \mathrm{~A}$ & $51.8 \pm 1.92 \mathrm{~B}$ \\
\hline
\end{tabular}
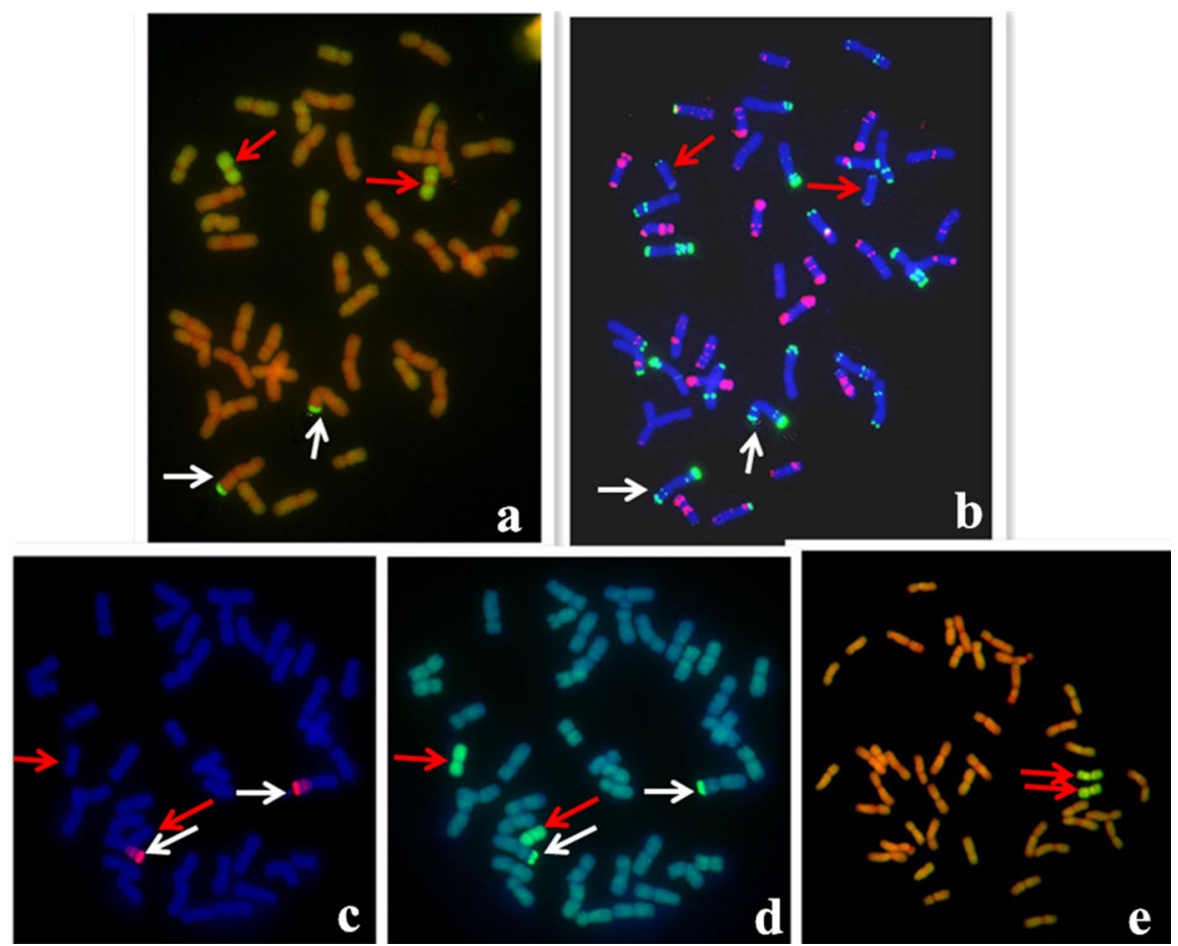

Fig. 2 In situ hybridization patterns of line 14-569. a, d GISH patterns using genomic DNA from Th. intermedium (green) as a probe. b ND-FISH pattern using Oligo-pSc119.2-1 (green) and Oligo-pTa535-1 (red) as probes. c GISH pattern using genomic DNA from rye (red) as a probe. e GISH pattern using genomic

from $S$. cereale and Th. intermedium as probes (Fig. 2c, d). The 1RS/1BL translocation chromosomes apparently originated from the wheat parent CN10. This result also indicated that the terminal DNA sequence of the rye 1RS chromosome has high homology with a DNA sequence of Th. intermedium. When the DNA from Ps. spicata was used as a probe, one pair of chromosomes exhibited the same hybridization signals as that the DNA from $T h$.
DNA from Ps. spicata (green) as a probe. The white arrows indicate $1 \mathrm{RS} / 1 \mathrm{BL}$ translocation chromosomes and the red arrows indicate added Th. intermedium chromosomes. (Color figure online)

intermedium was used as a probe (Fig. 2e), which indicated that this pair of chromosomes belonged to the St-genome, according to Chen et al. (1998). This result demonstrated that one pair of St genomic chromosomes was added to line 14-569, and it contained one pair of $1 \mathrm{RS} / 1 \mathrm{BL}$ translocation chromosomes in its wheat complement. 
Molecular marker analysis

On the basis of syntenic region in rice, Ishikawa et al. (2009) developed PLUG primers, of which the amplified fragments presumably corresponded to similar linkage group(s) in wheat genomes owing to the similarities in gene structure between rice and wheat (Ishikawa et al. 2007). In this study, a total of 105 PLUG markers distributed over homeologous groups 1-7 in wheat were employed to amplify specific bands due to line 14-569, CN10 and CS wheat, Th. intermedium and Ps. spicata. Ten PLUG markers, namely, TNAC1244, TNAC1267, TNAC1280, TNAC1307, TNAC1312, TNAC1344, TNAC1364, TNAC1379, TNAC1383 and TNAC1648, produced specific bands identical to those of Th. intermedium and Ps. spicata in the PCR profile of line 14-569 when CS and its wheat parent CN10 wheat were used as controls. As shown in Fig. 3, the PLUG markers TNAC1280 and TNAC1244 amplified diagnostic fragments of the long and short arms, respectively, of chromosomes in homeologous group 3, in accordance with descriptions by Ishikawa et al. (2009). Of the other eight PLUG primers, TNAC1307, TNAC1312, TNAC1383, and TNAC1648 amplified diagnostic fragments of the short arms, whereas the other four primers amplified diagnostic fragments of the long arms, of chromosomes in homeologous group 3. These results suggested that the added chromosomes from $T h$. intermedium in line 14-569 belonged to homeologous group 3. Therefore, we deduced that line 14-569 was a wheat-Th. intermedium 3St disomic addition line.

\section{Discussion}

Wheat-alien disomic addition lines are considered to be optimal bridge materials for transferring desirable genes into wheat and are also frequently used to study the expression of genes and the evolution of species (Zhong et al. 2002). Therefore, it is important to determine the genetic constitution of alien addition lines in order to produce translocations that compensate for the transfer of genes from alien chromosomes into wheat genomes.

In this study, we have identified one pair of chromosomes from Th. intermedium in wheat line 14-569 which exhibits a high level of resistance to stripe rust, which is currently a major global problem. At present, this chromosome is available as an addition line, which differs from normal wheat in several characters apart from resistance, such as 1000-kernel weight and double spikelets. Hence, it will be worthwhile to study line 14-569 further, and it can be used as a better bridge material for breeding wheat with high-yields and stripe rust resistance.

Sequential GISH and ND-FISH analyses indicated that one pair of St genomic chromosomes from $T h$. intermedium was added to the wheat complement and that the wheat complement included one pair of $1 \mathrm{RS} /$ 1BL wheat rye translocation chromosomes in this line. However, in situ hybridization was not able to assign the homeologous group of alien chromosomes in a wheat background. Hu et al. (2012) reported that PLUG markers were effective tools for producing markers that were specific to Thinopyrum chromosomes. PLUG markers that corresponded to the third linkage group in wheat generated diagnostic fragments from line 14-569 that were identical to those of
Fig. 3 PCR amplification profiles obtained using the PLUG primers TNAC1244 (a) and TNAC1280 (b). The white arrows indicate specific bands of the line 14-569 that are identical to those of Th. intermedium and Ps. spicata

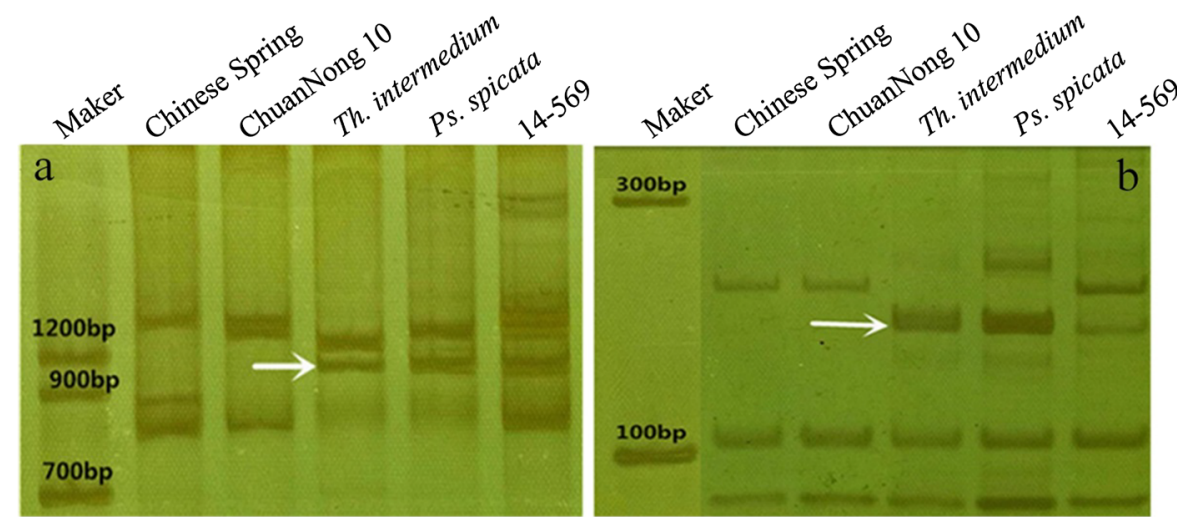


Th. intermedium and Ps. spicata (Fig. 3), which suggested that the St chromosome in line 14-569 belonged to homeologous group 3, and it was hence assigned as the $3 \mathrm{St}$ chromosome.

Several different St chromosomes from Th. intermedium have been transferred to a wheat background. A 1St (1D) substitution line (Hu et al. 2011), a 1St disomic addition line (Li et al. 2013) and a 7St disomic addition line (Song et al. 2013) in different wheat background have been reported. Two other wellknown groups of addition lines, namely, the $\mathrm{Z}$ and $\mathrm{L}$ series, were identified by Hu et al. (2014) using DNA markers, and they found that the Z3, L4, L6 and L7 lines were $1 \mathrm{St}, 4 \mathrm{St}, 2 \mathrm{St}$ and $6 \mathrm{St}$ disomic addition lines, respectively. However, there have been no reports of 3 St alien disomic addition lines in a wheat background until now.

Several stripe rust resistance genes have been mapped on the chromosomes of homeologous group 3 in wheat. $\operatorname{Yr} 76$ and $\operatorname{Yr} 57$ have been located on the short arms of the 3AS (Xiang et al. 2016) and 3BS (Randhawa et al. 2015) chromosomes, respectively. Both $Y r 45$ and $Y r 71$ have been located on the long arms of the 3D chromosome (Bariana et al. 2016; Li et al. 2011). The 3 Ns chromosome from Psathyrostachys huashanica Keng might also carry stripe rust resistance gene(s) (Kang et al. 2011). Recently, Zhang et al. (2018) reported recessive stripe rust resistance gene(s) might locate on the $3 \mathrm{~V}$ chromosome of Dasypyrum villosum. No stripe rust resistance gene present on the 3St chromosome has been reported, although stripe rust resistance genes from Th. intermedium have been transferred into wheat (Chen 2005a; $\mathrm{Hu}$ et al. 2011; Song et al. 2013). In the present study, line 14-569 appeared to be highly resistant to all the races of stripe rust predominant in China, which implied that the 3St chromosome of Th. intermedium might carry stripe rust resistance gene(s).

In general, a wheat spike normally bears one spikelet per rachis node, and it is rare that a rachis node carries two or more spikelets. Line 14-569 possesses the character of double spikelets, with an average of eight double spikelets per spike. Du et al. (2013) reported that a $6 \mathrm{Ns}$ disomic addition line derived from $P$. huashanica carried the same double spikelets as line 14-569. These results indicated that new character(s) might be produced in the progeny of hybrids of wheat with alien species. However, some aneuploid wheat plants have also possessed double spikelets in a rachis node, for example, hexaploid wheat plants that were nullisomic for the $2 \mathrm{~A}$ and $2 \mathrm{D}$ chromosomes produce double spikelets (Sears 1954). Further research will be needed to establish the association between the 3St chromosome and the specific spike trait.

Acknowledgements $\mathrm{We}$ are thankful to the Bureau of Education, Sichuan Province, China (No. 001Z1400) for financial support. In particular, we acknowledge the excellent technical assistance with molecular markers, provided by Dr. Zujun Yang, School of Life Science and Technology, University of Electronic Science and Technology of China. We also gratefully acknowledge Dr. A. J. Lukaszewski, Department of Botany and Plant Sciences, University of California, Riverside, CA 92521, USA for his review and helpful suggestions on the manuscript.

\section{Compliance with ethical standards}

Conflict of interest The authors declare that they have no conflict of interest.

Ethical standard This article does not contain any studies with animals performed by any of the authors.

Informed consent Informed consent was obtained from all individual participants included in the study.

Open Access This article is distributed under the terms of the Creative Commons Attribution 4.0 International License (http:// creativecommons.org/licenses/by/4.0/), which permits unrestricted use, distribution, and reproduction in any medium, provided you give appropriate credit to the original author(s) and the source, provide a link to the Creative Commons license, and indicate if changes were made.

\section{References}

Bariana H, Forrest K, Qureshi N, Miah H, Hayden M, Bansal U (2016) Adult plant stripe rust resistance gene $Y r 71$ maps close to $L r 24$ in chromosome 3D of common wheat. Mol Breed 36:98-107. https://doi.org/10.1007/s11032-0160528-1

Chen Q (2005a) Detection of alien chromatin introgression from Thinopyrum into wheat using S genomic DNA as a probea landmark approach for Thinopyrum genome research. Cytogenet Genome Res 109:350-359. https://doi.org/10. 1159/000082419

Chen XM (2005b) Epidemiology and control of stripe rust (Puccinia striiformis f. sp. Tritici) on wheat. Can J Plant Pathol 27:314-337. https://doi.org/10.1080/ 07060660509507230

Chen Q, Conner RL, Laroche A, Thomas JB (1998) Genome analysis of Thinopyrum intermedium and Thinopyrum ponticum using genomic in situ hybridization. Genome 41:580-586. https://doi.org/10.1139/gen-41-4-580 
Du W, Wang J, Pang Y, Li Y, Chen X, Zhao J, Yang Q, Wu J (2013) Isolation and characterization of a Psathyrostachys huashanica Keng 6Ns chromosome addition in common wheat. PLoS ONE 8:e53921. https://doi.org/10.1371/ journal.pone.0053921

Fedak G, Han F (2005) Characterization of derivatives from wheat-Thinopyrum wide crosses. Cytogenet Genome Res 109:360-367. https://doi.org/10.1159/000082420

Fu SL, Chen L, Wang YY, Li M, Yang ZJ, Ling Q, Yan BJ, Ren ZL, Tang ZX (2015) Oligonucleotide probes for ND-FISH analysis to identify rye and wheat chromosomes. Sci Rep 5:10552-10558. https://doi.org/10.1038/srep10552

Han F, Lamb JC, Birchler JA (2006) High frequency of centromere inactivation resulting in stable dicentric chromosomes of maize. Proc Natl Acad Sci USA 103:3238-3243. https://doi.org/10.1073/pnas.0509650103

He M, Xu Z, Zou M, Zhang H, Chen D, Pu Z, Hao S (1989) The establishment of two sets of alien addition lines of wheatgrass. Sci China Ser B 6:57-67

Hu LJ, Li GR, Zeng ZX, Chang ZJ, Liu C, Zhou JP, Yang ZJ (2011) Molecular cytogenetic identification of a new wheat-Thinopyrum substitution line with stripe rust resistance. Euphytica 177:169-177. https://doi.org/10.1007/ s10681-010-0216-x

Hu LJ, Liu C, Zeng ZX, Li GR, Song XJ, Yang ZJ (2012) Genomic rearrangement between wheat and Thinopyrum elongatum revealed by mapped functional molecular markers. Genes Genomics 34:67-75. https://doi.org/10. 1007/s13258-011-0153-7

Hu LJ, Li GR, Zhan HX, Liu C, Yang ZJ (2014) New St-chromosome-specific molecular markers for identifying wheatThinopyrum intermedium derivative lines. J Genet 93(Suppl 1):69-74. https://doi.org/10.1007/s12041-0120158-2

Ishikawa G, Yonemaru J, Saito M, Nakamura T (2007) PCRbased landmark unique gene (PLUG) markers effectively assign homoeologous wheat genes to A, B and D genomes. BMC Genomics 8:135. https://doi.org/10.1186/14712164-8-135

Ishikawa G, Nakamura T, Ashida T, Saito M, Nasuda S, Endo TR, Wu J, Matsumoto T (2009) Localization of anchor loci representing five hundred annotated rice genes to wheat chromosomes using PLUG markers. Theor Appl Genet 118:499-514. https://doi.org/10.1007/s00122-008-0916-y

Jiang J, Friebe B, Gill BS (1993) Recent advances in alien gene transfer in wheat. Euphytica 73:199-212. https://doi.org/ 10.1007/bf00036700

Kang H, Wang Y, Fedak G, Cao W, Zhang H, Fan X, Sha L, Xu L, Zheng Y, Zhou Y (2011) Introgression of chromosome 3 Ns from Psathyrostachys huashanica into wheat specifying resistance to stripe rust. PLoS ONE 6:e21802. https:// doi.org/10.1371/journal.pone.0021802

Kato A, Lamb JC, Birchler JA (2004) Chromosome painting using repetitive DNA sequences as probes for somatic chromosome identification in maize. Proc Natl Acad Sci USA 101:13554-13559. https://doi.org/10.1073/pnas. 0403659101

Li H, Conner RL, Murray TD (2008) Resistance to soil-borne diseases of wheat: contributions from the wheatgrasses Thinopyrum intermedium and Th. ponticum. Can J Plant Sci 88:195-205. https://doi.org/10.4141/cjps07002
Li Q, Chen XM, Wang MN, Jing JX (2011) Yr45, a new wheat gene for stripe rust resistance on the long arm of chromosome 3D. Theor Appl Genet 122:189-197. https://doi.org/ 10.1007/s00122-010-1435-1

Li GR, Liu C, Li CH, Zhao JM, Zhou L, Dai G, Yang EN, Yang ZJ (2013) Introgression of a novel Thinopyrum intermedium St-chromosome-specific HMW-GS gene into wheat. Mol Breed 31:843-853. https://doi.org/10.1007/ s11032-013-9838-8

Li G, Lang T, Dai G, Li D, Li C, Song X, Yang Z (2015) Precise identification of two wheat-Thinopyrum intermedium substitutions reveals the compensation and rearrangement between wheat and Thinopyrum chromosomes. Mol Breed 35:1-10. https://doi.org/10.1007/s11032-015-0202-z

Line RF, Chen X (1995) Successes in breeding for and managing durable resistance to wheat rusts. Plant Dis 79:1254-1255

Liu W, Seifers DL, Qi LL, Friebe B, Gill BS (2011) A compensating wheat-Thinopyrum intermedium Robertsonian translocation conferring resistance to wheat streak mosaic virus and Triticum mosaic virus. Crop Sci 51:2382-2390. https://doi.org/10.2135/cropsci2011.03.0118

McIntosh RA, Dubcovsky J, Rogers WJ, Morris C, Xia XC (2017) Catalogue of gene symbols for wheat: 2017 supplement. https://shigen.nig.ac.jp/wheat/komugi/genes/ macgene/supplement2017.pdf

Randhawa MS, Bariana HB, Mago R, Bansal UK (2015) Mapping of a new stripe rust resistance locus $Y r 57$ on chromosome 3BS of wheat. Mol Breed 35:65-72. https:// doi.org/10.1007/s11032-015-0270-0

Roelfs AP, Singh RP, Saari EE (1992) Rust diseases of wheat: concepts and methods of disease management. CIMMYT, Mexico

Sears ER (1954) The aneuploids of common wheat. Mo Agric Exp Station Res Bull 572:1-58

Song X, Li G, Zhan H, Liu C, Yang Z (2013) Molecular identification of a new wheat-Thinopyrum intermedium ssp. Trichophorum addition line for resistance to stripe rust. Cereal Res Commun 41:211-220. https://doi.org/10.1556/ crc.2013.0009

Sun S (1981) The approach and methods of breeding new varieties and new species from Agrotriticum hybrids. Acta Agron Sin 7:51-58

Tang S, Li Z, Jia X, Larkin PJ (2000) Genomic in situ hybridization (GISH) analyses of Thinopyrum intermedium, its partial amphiploid Zhong 5, and disease-resistant derivatives in wheat. Theor Appl Genet 100:344-352. https://doi.org/10.1007/s001220050045

Xiang C, Feng J, Wang M, Chen X, See D, Wan A, Wang T (2016) Molecular mapping of stripe rust resistance gene $Y r 76$ in winter club wheat cultivar Tyee. Phytopathology 106:1186-1193. https://doi.org/10.1094/phyto-01-160045-fi

Yang Z, Li G, Chang Z, Zhou J, Ren Z (2006) Characterization of a partial amphiploid between Triticum aestivum cv. Chinese Spring and Thinopyrum intermedium ssp. trichophorum. Euphytica 149:11-17. https://doi.org/10.1007/ s10681-005-9010-6

Yang M, Ren T, Yan B, Li Z, Ren Z (2014) Diversity resistance to Puccinia striiformis f. sp tritici in rye chromosome arm 
1RS expressed in wheat. Genet Mol Res 13:8783-8793. https://doi.org/10.4238/2014.october.27.20

Zhang J, Jiang Y, Wang Y, Guo Y, Long H, Deng G, Chen Q, Xuan P (2018) Molecular markers and cytogenetics to characterize a wheat-Dasypyrum villosum 3 V (3D) substitution line conferring resistance to stripe rust. PLoS ONE 13:e0202033. https://doi.org/10.1371/journal.pone. 0202033
Zhong GC, Mu SM, Zhang ZB (2002) Wide hybridization of Triticeae species. Science Publisher, Beijing

Publisher's Note Springer Nature remains neutral with regard to jurisdictional claims in published maps and institutional affiliations. 